ELS Journal on Interdisciplinary Studies on Humanities

Volume 1 Issue 3, 2018

ISSN (print) : 2621-0843

ISSN (online) : 2621-0835

Homepage : http://journal.unhas.ac.id/index.php/jish

\title{
Code Switching on Students' Group Presentation in EFL Classroom
}

\author{
Harmilawati ${ }^{1}$ \\ harmila1986@gmail.com
}

\begin{abstract}
The study aimed to find out the functions of code switching used by the lecturer and the students during group presentation, and the lecturer and the students' perception toward the use of code switching in EFL classroom during group presentation. This study is a qualitative research design. The subjects of the study were an English lecturer and three students in second semester of STKIP Muhammadiyah Bone, which were taken through convenience sampling technique. The data of this study were collected by employing classroom observation and interview. The data obtained were analyzed descriptively by using three steps, namely reducing, describing, and classifying. The result of the research showed that the lecturer employed code switching in EFL classroom during the students' group presentation for some functions, namely to emphasize the important point, to reinforce a request, to ease of expression, to change of attitude relationship, checking for students' understanding, lapses, self-correction, and speech connective. To emphasize the important point and reinforce a request became most frequently used by the lecturer. There were five functions of code switching used by the students during group presentation, namely to emphasize the important point, to suit the domain knowledge, to reinforce a request, to change of attitude relationship, and to selfcorrection. To suit the domain knowledge became the most frequently used by the students. The lecturer and the students' perception towards the use of code switching in EFL classroom during group presentation were mostly positive. The lecturer and the students need code switching in teaching and learning English because it can make them easy to understand and comprehend from the material given. Code switching also effective in enlarging the students' vocabulary, helped them to learn English, made them be more active in classroom interaction and influenced their fluency in speaking English.
\end{abstract}

Keywords: Code Switching, Students' Group Presentation

How to cite: Harmilawati. (2018). Code Switching on Students' Group Presentation in EFL Classroom. ELS Journal on Interdisciplinary Studies in Humanities, 1(3), 297-308.

\section{Introduction}

Communication in the classroom sometimes we found in oral presentation, either between students and students or between teacher and students. The teacher or lecturer mostly uses oral presentation in presenting the material in front of the class. However, nowadays, oral presentation also becomes an activity in presenting the materials that can be done by the students. In oral presentation, the English teachers and students sometimes switch their language to explain clearly about the

\footnotetext{
${ }^{1}$ Institut Agama Islam Muhammadiyah Sinjai
} 
subject. So commonly, the English teachers/ lecturers and students may be mindful to switch language while they are presenting the materials in the class.

In EFL classroom, the language used by the teacher and students in teaching and learning process is usually English, but both of the lecturer and students still feel any difficulties when using English because that language is not used in their daily life. In order to minimize it, there are many strategies that can be used by some nonnative English teachers. One of them is using code switching in their classroom. Code switching in this case means that the teacher switches her/his language during the teaching and learning process, whether from Indonesia to English or vice versa.

Wardhaugh (2006) said that the phenomenon of code switching is found in bilingual or multilingual society, because they are commonly required to select certain of code whenever they choose to speak, and they may also switch from one language to another language. Thus, it is feasible to conduct a study on code switching by involving the members of the bilingual or multilingual society who are supposed to switch the language. Indonesian people who live in a bilingual or even multilingual society enable to switch code in daily communication, like at school or the other public educational places.

This research was intended to answer the following questions: (1) what are the functions of code switching used by the EFL lecturer in the EFL classroom during the students' group presentation? (2) what are the functions of code switching used by the EFL students in the EFL classroom during the students' group presentation? and (3) what are the lecturer's and students' perceptions towards the use of code switching in the EFL classroom during the students' group presentation?

\section{Literature Review}

\subsection{Group presentation}

Oral presentation is a kind of activity of communicating ideas and information in front of the audiences. Al-Issa and Al-Qubtan (2010), states that oral presentation is one of activity, which can encourage students to take initiative, think beyond the mandated textbook, and use language creatively, purposefully, and interactively, and an important feature of the EFL classroom in different parts of the world. Thus, the students are taught to improve their creativity through the language. According to King (2002), oral presentation is an effective communicative activity that has been widely adopted by EFL conversation teachers to promote oral proficiency.

Based on definitions above, the researcher concludes that oral presentation is an activity of sharing ideas and or information in front of audiences which has purpose to improve students' oral proficiency.

Oral presentations are a common feature of many courses at university. They may take the form of a short or longer presentation at a tutorial or seminar, delivered individually or as part of a group.

According to King (2002), there are two kinds of oral presentation as follows:

\section{Individual Presentations}

The benefits of individual presentations include helping students to gain confidence while speaking on their own in front of a large group, or to take personal responsibility for critically understanding and responding to questions. In the process, students become localized "experts" on certain subjects. 
2. Group Presentations

There are substantial benefits to assigning presentations in groups. Groups encourage teamwork and help students get feedback from each throughout the process of developing the presentation. Groups can prepare presentations during or outside of class.

Group presentations require students to work together to plan and prepare for their presentation. During group work students can be encouraged to use English to negotiate meaning with the other members of their group and to work together, in English, to plan how they will present their ideas to the other members of the class. This facilitates English use to meet a specific goal, in an authentic way, and with very little intervention from the teacher (Brooks \& Wilson, 2014).

\subsection{Code switching}

In sociolinguistics, the speaker uses a term to perform language style which is called "code". Someone use code when they want to emphasize the uses of a language or language variety in a particular society. Wardhaugh (2002) stated that code switching is a process when people are habitually required to choose a particular code whenever they want to speak, and they may also choose to change from one code to another or two mix codes even within sometimes very little utterances and thus create a new code. Holmes (1992) stated that code switching occurs when the speaker shifted their language from one language to another. She also stated that code switching is a common term for alternate use of two or more language or varieties of language that can be functioned as sentences, clause, phrase or even a word.

\subsection{The functions of code switching in EFL classroom}

There are eleven functions of code switching that proposed by Baker (2006). Those are:

1. To emphasize the important point

2. To suit a domain knowledge

3. To show unequivalence

4. To reinforce a request

5. To show family bonding or friendship

6. To suit of the language

7. To interject a conversation

8. To make easier of expressing the tension or emotion to conversation

9. Can show a change of attitude relationship

10. To exclude people from a conversation

11. To talk certain topic 


\section{Method}

\subsection{Design and Samples}

This research is under design of descriptive qualitative research. The participants of this research were chosen through convenience sampling technique. The researcher focuses on classroom observation and interview. An English lecturer and three students from second semester of English Education program at STKIP Muhammadiyah Bone were involved in this research to find out the functions of code switching used by the lecturer and the students in EFL classroom and to know the lecturer's and the students' perception toward the use of code switching during students' group presentation.

\subsection{Data collection}

The researcher applied classroom observation and structured interview in this research by doing these following procedures:

1. The researcher met the lecturer to know the schedule.

2. The researcher asked permission to the English lecturer and the students of second semester in STKIP Muhammadiyah Bone for observing and interviewing them.

3. Having the permission, the researcher joined into their class for three group presentation performances separately and employed direct observation as the first step to get the data. The observation was administered in classroom and mainly observed the use of code switching by the lecturer and students during the students' group presentation. During the observation, the researcher analyzed the occurrence of code switching through theory by Baker (2006) to find out the functions of code switching used by the lecturer and students during group presentation. Moreover, the researcher recorded all the group presentation process in the classroom in order to avoid the loosing of data needed.

4. Having observing the students' group presentation, the researcher interviewed them (three students) for approximately 10 minutes of each separately. The questions were directed to the students and focused on the functions of code switching used by the lecturer and students during group presentation and the students' perception toward it.

\subsection{Data Analysis}

The researcher did transcription in analyzing data was to identify the data which had gotten from the observation, recorder, and interview. The data was analyzed by using descriptive qualitative method. The data was transcribed into written transcript, and then was identified, selected, and also classified based on the analyzing needs which was relevant to the mode from Miles and Huberman (1994) through the follow steps: data reduction, data description, and data classification.

The data from the observation and recording firstly was transcribed into the written transcript. The transcript was identified to determine the utterances that considered as the code switching phenomenon and the utterances that were not contained code switching were omitted, so that the utterances that are contained code switching left. By data reduction, the researcher identified and chooses the data, i.e. the utterances that were considered as code switching, which was relevant 
Harmilawati. 1(3): 297 - 308

to the research topic, so that the analysis was focused into the data that was suitable to the research questions that had been formulated.

The data that had been reduced then was described as the research data that contains code switching. This data was analyzed through descriptive qualitative method to find out the functions of code which might appear during group presentation.

The data which had been reduced and described was classified into specific groups based on the research focus. The focuses of the research were referred to the functions of code switching.

In other to get further information about the use of code switching by the lecturer and students during group presentation, after the steps above, the researcher applied interview to the students who were used code switching during presentation. Interview supported the data from the observation and recording. This was intended to enrich the information had been gotten before. The interview was focused into the awareness of the students in using code switching during the group presentation and the students' perceptions toward it.

\section{Findings}

\subsection{The functions of code switching used by the lecturer in EFL classroom during the students' group presentation}

The data from the observation in the classroom during students' group presentation in the first and the second meetings were found only eight functions of code switching that the lecturer used. Those are to emphasize the important point, to reinforce a request, to ease of expression, to change of attitude relationship, checking for students' understanding, lapses, self correction, and speech connective. In this case, the researcher would like to provide the description of the samples analyzed as follows:

\section{a. To emphasize the important point}

One reason why someone switches his language, maybe for stressing one important point. For example in teaching pronunciation practice. It is occurs when the lecturer want or sees a need to explain how to pronounce English words. This function takes place when the lecturer correct the students' pronunciation using as illustrated from the researcher's finding in extract below. This extract was taken from the observation by video and audio recording which was taken on Tuesday, $31^{\text {st }}$ May, 2016.

PT : Thanks for the change that given to us

L : Bukan us tapi us [^s]. Us .. U..S .. United State, right? us disini adalah kami.

: Not us but us[^s]. Us .. U .. S .. United State, right? Us here is we are.

The extract above shows one function of code switching that used by the lecturer in the second students' group presentation. In this case, the lecturer was explaining the students the appropriate pronunciation of the word 'us' by saying 'bukan us tapi us [^s]'. The lecturer's utterance was in Indonesian but he switched his language to English when pronouncing the word 'us'. 


\section{b. To reinforce a request}

Code switching is sometimes used to reinforce a request. The teacher switches from English to reinforce his request.

DJ : Ok .. I want to ask ...

L : Stand up please!

DJ : (still sat down)

L : Stand up please! Berdiri! 'Stand up please! Stand up!

The extract above shows function of code switching to reinforce a request used by the lecturer in the first students' group presentation. In this case, the lecturer switched his code to make instruction comprehensible for the students, he switched the language from English to Indonesian by saying "Stand up please! Berdiri!'. Thus, the student was expected to able to understand the instruction better, and then she was also expected to be able do the instruction correctly.

\section{c. Ease of expression}

The function of code switching is to make someone easy to express their feelings. For example, the lecturer switches his language to express his anger to the students. This extract was taken from the observation by video and audio recording which was taken on Tuesday, $31^{\text {st }}$ May, 2016.

$\mathrm{L}$ : Have you another question? Sudah dicatat pertanyaannya? Hello!

Have you another question? Have you wrote the question? Hello!'

It can be seen in extract above that the lecturer employed code switching in the first group presentation by using the word 'hello' after his Indonesian utterance. The lecturer wanted to asked the students whether the question is already noticed or not. The word 'hello' was an English interjection. It is used by the lecturer to get the students attention by expressed his tension.

\section{d. Change of attitude relationship}

In teaching and learning process, the lecturer usually give comment to the students. When giving a comment to the bilingual students, sometimes the lecturer show up his identity to make a relax circumstance in the classroom by using local language. This extract was taken from the observation in the first group presentation on Tuesday, $31^{\text {st }}$ May, 2016.

L : Can you underline it? Tolong garis'ki di papan tulis!

: Can you underline it? Please underline it on the white board!' (PT underlines the wrong word)

L : Eee .. kagarisi-garisi di'. Coba yang mana preposisinya disitu?

: 'Eee ..[you] just underlining it [underlined the wrong word]. Where is the preposition in that sentence?

The extract above shows, the lecturer used his local language in teaching process to created the an enjoy or relax circumstance. It can be seen when the lecturer used Buginese in his utterance by saying 'eee .. kagarisi-garisi di' and all of the students laughs heard it because the students understood their lecturer's utterance. The function of code switching to change of attitude relationship only found by the researcher in the first group presentation. 


\section{e. Checking for students' understanding}

Another function of code switching out of the Baker's theory that the researcher found is to check the students' understanding. In questioning and answering section on the students' group presentation, the lecturer should make sure that all students know all the word in that activity. If there are new words or unknown words, the lecturer can ask the students what he means. The lecturer sometimes needs to check the students' understanding in order to determine how far the students have comprehended from the material. The following extracts are the examples of the application of code switching in order to check the students' understanding.This extract was taken from the observation by video and audio recording which was taken on Tuesday, $31^{\text {st }}$ May, 2016.

$\mathrm{L} \quad$ : To present the material not presentage the materi. There is no meaning of presentage in the dictionary. Jadi harusnya present. Materi is Indonesian word. What is the English of materi?

: 'To present the material not presentage the material. There is no meaning of presentage in the dictionary. It should be present. Material is Indonesian word. What is the English of material?

The extract above shows code switching that used by the lecturer. The lecturer employed code switching as he switched from English when he said 'what is the English of' to Indonesian for the word 'materi' when he wanted to ask the students about the English of materi. His question was in English but he used an Indonesian word materi in his question. The function of code switching here is checking for students' understanding. In this situation, the lecturer did not translate the word materi but he asked the students the English of the word. By switching to Indonesian, he let the students participate more actively.

\section{f. Lapses}

Lapses are instances where the lecturer is speaking Indonesian but says a word or a couple of words in English. These English words can be spoken almost accidentally or not purely accidental but the lecturer partly knows he is using English. The lecturer in the present data has a few lapses during the students' presentation. The following extracts demonstrate what exactly were meant by lapses. This extract was taken from the observation by video and audio recording which was taken on Tuesday, $31^{\text {st }}$ May, 2016 in the first group presentation.

L : Itumi saja tadi yang dislide mutampilkan baru jelaskan bagian-bagiannya. Ya .. yang itu saja dislide!

' Just display the slide and explain the parts. Yaa .. those are on the slide!

In this extract, the lecturer employed code switching as he switched from Indonesian to English and back to Indonesian again when he said 'itumi saja yang di slide mutampilkan baru jelaskan bagian-bagiannya. Ya ...yang itu saja di slide!. He gave instruction in Indonesian but he inserted an English word 'slide' in his instruction. The reason of the lecturer used an English word in this situation because he presumed that the student have been familiar with this word. Here code switching is treated as lapses. 


\section{g. Self correction}

The function of self correction in code switching is quite common in EFL classroom. The lecturers employ self-correction in their utterance by beginning it in TL but inserting one word or a couple of words in L1 in the middle of the utterance. When self correction occurs, a lecturer is usually producing a sentence and when he realize that a mistake has occurred in his sentence, he corrected it by inserting a L1 word and then continuing in the TL, but now with a more correct answer.

RR : Eemm..example preposisi dalam bentuk teks Pak

'Eemm .. example of preposition in text, Sir'

$L \quad$ : Ya .. in text form ... ehh .. dalam kalimat. Sentence I mean.

Yes... another questions?

'Ya .. in text form .. ehh .. in sentence. Sentence I mean.

Yes .. [have you] another questions?

This extract was taken from the observation by video and audio recording which was taken on Tuesday, $31^{\text {st }}$ May, 2016 in the first group presentation. The researcher do not found the function of code switching for self correction in the second group presentation.

\subsection{The functions of code switching used by the students in EFL classroom during the students' group presentation}

There were three students became the participant in this study. They are PT, DJ and SF. The data had shown that there were five functions of code switching used by the students found by the researcher during the students' presentation in the first and second presentations. Those were to emphasize the important point, to suit the domain knowledge, to reinforce a request, to change of attitude relationship, and to self correction.

\section{a. Emphasize the important point}

Emphasize is one reason why someone switches his language, maybe for stressing one important point. For example, she speaks English, then in her talk, she think anything is very important, sometimes she change her language to Indonesian to show her interlocutor the important point in the new language she use. It is occurs when the students wants or sees a need to explain the given answer. This function can be seen in the extract below that taken from DJ's utterance in the first group presentation.

DJ : The function of prepositional phrase. Kan dia berfungsi jadi adverb ketika modifier a verb, adjective and another adverb.

'The function of prepositional phrase. The function of [prepositional phrase] is adverb when its modifier a verb, adjective or another adverb.

The extract above shows ones function of code switching that used by the student (DJ) in first group presentation when she repeated her question to make the moderator understood what her question meant or what she said, she emphasize certain words in her question by inserting the first language. DJ used English in the beginning by saying 'the function of prepositional phrase' then switched to Indonesian by saying 'kan dia berfungsi jadi' and inserted an English word 'adverb' 
then switched again to Indonesian by saying 'ketika' and altered again to English by saying 'modifier a verb, adjective and another adverb'.

\section{b. To suit the domain knowledge}

Code switching as a suit the domain of knowledge in students' group presentation is shown in the following extract:

PT : Thanks for the change that given to us to presentation .. eh .. to present the material and I give time to Rika to <Xword > my materi.

'Thanks for the change that given to us to presentation .. eh .. to present the material and I give time to Rika to <Xword> my material.

The extract above shows the function of code switching to suit the domain knowledge as a function of code switching used by the third students in the first and second group presentation. In this case, the third students used code switching because they did not know the word in English, "Thanks for the change that given to us to presentation .. eh .. to present the material and I give time to Rika to <XwordX $>$ my materi."

\section{c. To reinforce a request}

The function of reinforce a request is employed by the students when they asked to their friends to did something during the students' presentation, such as ask their friends to giving question.

PT : (confused about DJ's question). Can u repeat your question? Tolong diulang coba!

'(confused about DJ's question). Can u repeat your question? Tolong diulang coba!

The extract above shows function of code switching to reinforce a request used by the third students. In this case, PT as the presenter in the first group presentation switched her code when she asked her friend to repeat the question by saying "can you repeat your question' and repeat her question by translating her sentence by saying 'tolong diulang coba'. Thus, the student who gave the question before was expected to able to understand the instruction better, and then she was also expected to be able do the instruction correctly.

\section{d. To change of attitude relationship}

In teaching and learning process, the students usually give comment or ask to the other students. When giving a comment or asking question to the bilingual students, sometimes the students show up his identity by using their local language to create sense of belonging of them or to show the politeness.

This extract was taken from the observation by video and audio recording which was taken on Tuesday, 31 ${ }^{\text {st }}$ May 2016.

$\begin{aligned} \text { NS : } & \text { Ooo..iya. Makasih. } \\ & \text { 'Ooo .. yes. Thank you.' }\end{aligned}$

PT : Next question from eee.. pertanyaanta' Dwi di’?

'Next question from eee .. is it your question [Dwi], isn't it?' 
The extract above, the student or presenter used his local language when she asked the student who has the question. It can be seen when the student slipped Buginese in his utterance in Indonesian to make sure herself that she did not wrong by saying 'next question from' eee.. pertanyaanta' Dwi di'. She used combination language between Indonesian and Buginese by saying 'pertanyaanta'. Ta' in Buginese show the politeness.

\section{e. To self correction}

The function of self correction in code switching is quite common in EFL classroom. The student employed self correction in her utterance by beginning it in L1 but inserting one word or a couple of words in TL in the middle of the utterance. When self correction occurs, a student is usually producing a sentence and when she realize that a mistake has occurred in her sentence, she corrected it by inserting a L1 word and then continuing in the TL, but now with a more correct answer. It can be seen in the following extract that was taken from the observation by video and audio recording which was taken on Tuesday, $31^{\text {st }}$ May 2106.

PT : Next question from eee.. pertanyaanta' Dwi di'?

Next question from eee .. is it your question [Dwi], isn't it?'

DJ : Iya

'Yes'

PT : Contoh kalimat .. emm .. sentence .. dan bagian-bagiannya. Emm...

'example of sentence .. emm .. sentence .. and it's parts [of that sentence]. Emm

The extract above shows the student used code switching to self correction when she realize that she use Indonesian in the beginning by saying 'contoh kalimat .. ee' and switched quickly her language when she realize that she know the English word of kalimat by saying it in English 'sentence' and then she using back Indonesian by saying 'dan bagian-bagiannya'.

\subsection{The lecturer and the students' perception toward the use of code switching in EFL classroom during the students' group presentation}

\section{a. The lecturer's perception}

There were six questions that the researcher asked to the lecturer about his opinion and perception of code switching and mostly of them gave positive effect to the use of code switching during the students' group presentation. It can be seen from the interview result below.

Dampak positifnya yaitu the students can understood the material better, dapat menangkap isi dari materi dengan baik, dan emm .. ee .. siswa juga lebih aktif pada saat pembelajaran khususnya tanya jawab. Ada feed back nya dari siswa. Terus .. kalau negatifnya itu dapat menurunkan motivasi siswa dalam mengembangkan kompetensi bahasa Inggrisnya atau dengan kata lain .. dapat mengurangi keinginan mereka dalam menguasai kata-kata Inggris. (The possitive effects (from code switching) are the students can understood the material better, can caught the content of the material well, and emm ... ee ..the students also be more active in learning, especially in quastion and answer section. There were feedback from the students. Then .. the negative impact from code switching were can demotivated the students in develop their English competence. It can 
Harmilawati. 1(3): $297-308$

reduce the students' willingness to master the English words'. (Lecturer DD: $14^{\text {th }}$

June, 2016)).

Based on the interview result above, the lecturer agree toward the use of code switching in the EFL classroom and he assume that the use of code switching gave positive impact to the students to increase the students' comprehending.

\title{
b. The students' perception
}

There were seven questions that the researcher asked to the third students about their opinion and perception of code switching and mostly of them gave positive effect to the use of code switching during the students' group presentation. It can be seen from the interview result below.

\begin{abstract}
Menurutku, yang paling membantu adalah ketika dosen beralih ke bahasa Indonesia .. karena tidak semua apa yang na ucapkan dosen bisa dimengerti dengan baik. Jadi menurutku beralih kode ke bahasa Indonesia sangat membantu. (According to me, the most helpful is if the lecturer switches to Indonesian .. because certainly not all English spoken by the lecturer can be understood well, so it is very helpful if the lecturer switch to Indonesian. (Student DJ : $21^{\text {st }}$ June, 2016)).
\end{abstract}

Based on the interview result above, the students agree toward the use of code switching in the EFL classroom and they assume that the use of code switching gave positive impact to them, especially to make them easier to understand the given material.

\section{Discussion}

Based on the findings above about the functions of code switching that used by the lecturer and the students, the researcher found that the lecturer used code switching for more reasons or functions than the students did. The similarities from the reasons triggering of code switching used by the lecturer and the students that they were mostly used code switching during the group presentation to emphasizing the important point of material being studied and to reinforce a request to got the students' or their classmates' attention from the given instruction. The difference functions of code switching used by the lecturer and the students is the lecturer did not use code switching to suit the domain knowledge, whereas the students used it for several time during group presentation.

\section{The lecturer and the students' perception toward the use of code switching in EFL classroom during the students' group presentation}

Based on the interview result that the researcher did to the lecturer and the students, they mostly gave positive effect of the used of code-switching during group presentation, especially to get the students' understanding from the given material and to transfer the knowledge to the students in an efficient way.

\section{Conclusion}

Based on the result of the data analysis, it can be concluded that, first, there were eight functions of code switching that used by the lecturer during students' group presentation, namely: emphasize the important point, reinforce a request, ease of expression, change of attitude relationship, checking for understanding, lapses, self-correction, and speech connective. Lapses, self-correction, and speech connective were the other functions of code switching out of Baker's theory. 
Emphasize the important point and reinforce a request were the most frequently used by the lecturer during students' group presentation, while self correction was the least frequently. Furthermore, the researcher found that in the represented campus, the influence of indigenous or local language cannot be avoided in the classroom. Indonesian that is used by the lecturer are Indonesian that is influenced by Buginese. It can be seen from the use of Buginese pronoun $k i$ in some of her expressions. Second, the students employed code switching during group presentation for some functions. The function of code switching may vary according to the context, situation, and the topic of the conversation. The data from the observation had shown that there were five functions of code switching used by the students, namely to emphasize the important point, suit the domain knowledge, reinforce a request, change of attitude relationship, and self-correction. Those functions based on the students' confirmation. Suit the domain knowledge became the most frequently used by the students during students' group presentation.

\section{References}

Al-Issa, S., \& Al-Qubtan, R. (2010). Taking the Floor: Oral Presentations in EFL Classrooms. A Free Article from TESOL Journal, 1(2)

Baker, C. (2006). Foundations of Bilingual Education and Bilingualism. Canada: Multilingual Matters Ltd.

Brooks, G., \& Wilson, J. (2014). Using Oral Presentations to Improve Students' English Language Skills. Humanities Review Vol.19. Japan: Kwansei Gakuin University

Holmes, J. (1992). An Introduction to Sociolinguistics, England: Pearson Education Limited.

King, J. (2002). Preparing EFL Learners for Oral Presentations. The Internet TESL Journal, Vol. VIII, No. 3

Miles, M. B., \& Huberman, A.M. (1994). Qualitative Data Analysis: An Expanded Sourcebook. California: SAGE Publications

Wardhaugh, R. (2006). An Introduction to Sociolinguistics. (5th Ed). Oxford: Blackwell. 